\title{
Tracking PCB Contamination in Ontario Great Lakes Tributaries: Development of Methodologies and Lessons Learned for Watershed Based Investigations
}

\author{
Nadine Benoit1, Alice Dove², Debbie Burniston², Duncan Boyd ${ }^{1}$ \\ ${ }^{1}$ Environmental Monitoring and Reporting Branch, Ontario Ministry of the Environment and Climate Change, \\ Ontario, Canada \\ ${ }^{2}$ Water Quality Monitoring and Surveillance Division, Science and Technology Branch, Environment Canada, \\ Ontario, Canada \\ Email: nadine.benoit@ontario.ca
}

Received 18 January 2016; accepted 23 February 2016; published 26 February 2016

Copyright (C) 2016 by authors and Scientific Research Publishing Inc.

This work is licensed under the Creative Commons Attribution International License (CC BY). http://creativecommons.org/licenses/by/4.0/

(c) (i) Open Access

\section{Abstract}

Project Trackdown is an investigative environmental program aimed at tracking sources of polychlorinated biphenyl (PCB) contamination in Great Lakes tributaries. The program uses a multimedia weight of evidence approach for identifying sources of PCBs to the environment. PCB concentrations in environmental media (sediment, water, suspended sediment and soil), passive samplers and/or exposed biota (mussels, young-of-the-year fish and benthic invertebrates) are used in combination to evaluate bioavailability and identify local anomalies within a tributary. These lines of evidence can be assessed with simple chemometric techniques and fingerprinting of PCB congener profiles, and, combined with anecdotal information such as land use history and tributary alterations, may be used to identify ongoing and locally controllable sources of PCBs to the Great Lakes. The program was successful at developing environmental triggers to differentiate potential source areas from background PCB conditions in urban areas, allowing efforts to focus on identifying active ongoing sources of PCB contamination. Project Trackdown has been carried out in three tributaries to Lake Ontario (Cataraqui River, Etobicoke Creek and Twelve Mile Creek) and two tributaries that flow into the Detroit River (Turkey Creek and Little River). Local ongoing PCB sources have been identified in four projects, leading to abatement or remediation measures. As a collaborative initiative between the Ontario Ministry of the Environment and Environment Canada, Project Trackdown has successfully identified several PCB sources leading to substantial cleanup efforts aimed ultimately at reducing PCB contamination to the Great Lakes. 


\section{Keywords}

\section{Source Tracking, PCBs, Great Lakes Tributaries}

\section{Introduction}

Maintenance and improvement of the environmental health of the Great Lakes represent an ongoing international and multi-jurisdictional challenge to scientists and the policy experts who work with them. Binational Lakewide Management Plans (LaMPs) have served to identify critical pollutants and the most pressing environmental issues that need to be addressed in each of the Great Lakes.

As part of commitments to conduct specific watershed investigations focused on identifying pollutant sources to the Great Lakes, the Ontario Ministry of the Environment (OMOE) and Environment Canada (EC) have been collaborating to identify and address watershed-specific contamination of polychlorinated biphenyls (PCBs) in tributaries representing a significant source to the Great Lakes.

Initiated as a pilot study in 2001 to determine the feasibility of finding locally significant sources of contaminants as ubiquitous as PCB, Project Trackdown's approaches to tracking sources of contamination were developed in three tributaries along the Canadian shoreline of Lake Ontario (Figure 1): Cataraqui River (Kingston, ON), Etobicoke Creek (Toronto, ON) and Twelve-Mile Creek (St. Catharines, ON). These tributaries were selected within three OMOE regional districts along Lake Ontario, to encompass a range of land uses in watersheds of varying size, where screening-level data were available from both provincial and federal studies (Table 1). Ambient monitoring programs had previously identified these tributaries as potential candidate watersheds with PCB concentrations in young-of-the-year (YOY) forage fish [1], sediment [2]-[5] and/or PCB concentrations in surface water (via large-volume sampling) [6] that exceeded applicable provincial and federal guidelines. Upon the availability of tributary mouth sediment quality results from Environment Canada [7], the project was expanded to include two additional tributaries (Turkey Creek and Little River) on the Canadian side of the Detroit River Area of Concern (AOC) (Figure 1).

The pilot study was conceptualised following the successes of previous source tracking studies in New York State, where a series of investigations and trackdown activities in sewersheds led to the successful abatement and remediation of existing PCB problems [10]. Our approach builds on the bracketing techniques used in the U.S. studies but also develops qualitative triggers for identifying probable sources. We use information herein from each of our study sites compiled over the years to assess the efficacy of the techniques used in Project Trackdown.

The goal of Project Trackdown was to determine whether it is possible to identify ongoing locally controllable sources of PCB contamination within Ontario watersheds. PCBs were chosen as the target pollutant as they are the primary contaminant responsible for fish consumption advisories in the Canadian Great Lakes [11] and

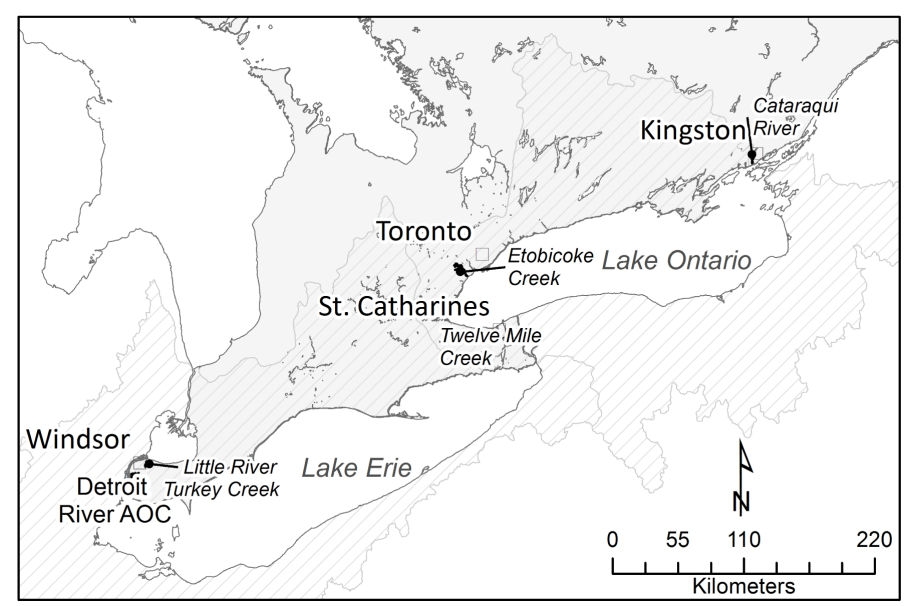

Figure 1. Location of Project Trackdown study sites in the Lake Ontario and Lake Erie basins. 
Table 1. Available PCB concentrations in various media from tributary mouths, that helped guide decisions to target watersheds for PCB Trackdown.

\begin{tabular}{|c|c|c|c|}
\hline Tributary & Surface water & Sediment & YOY forage fish \\
\hline Initial guidelines considered: & 1 ng/L (PWQO) [53] & $\begin{array}{l}70 \text { ng/g LEL [45] } \\
277 \text { ng/g PEL [44] }\end{array}$ & 100 ng/g [17] \\
\hline Tresholds adopted & $>10 \mathrm{ng} / \mathrm{L}$ & $277 \mathrm{ng} / \mathrm{g}$ & $200 \mathrm{ng} / \mathrm{g}$ \\
\hline $\begin{array}{l}\text { Cataraqui River, } \\
\text { Kingston } \mathrm{ON}^{1}\end{array}$ & $\mathrm{n} / \mathrm{a}$ & $\begin{array}{l}225 \mathrm{ng} / \mathrm{g}[2] \\
420 \mathrm{ng} / \mathrm{g}[3] \\
3000 \mathrm{ng} / \mathrm{g}[4]\end{array}$ & 40 - 540 ng/g wet [4] \\
\hline \multirow[b]{2}{*}{$\begin{array}{l}\text { Etobicoke Creek, } \\
\text { Toronto ON }\end{array}$} & \multirow[b]{2}{*}{$\begin{array}{c}\text { Mean } 3.7 \mathrm{ng} / \mathrm{L} \\
\text { (CI: } 1.6-8.8, \mathrm{n}=21 \text { ) Dry, } 19.1 \mathrm{ng} / \mathrm{L} \\
\text { (C.I.:6.7 - 54.7, } \mathrm{n}=16 \text { ) Wet [8]; } \\
\text { Identified as highest PCB load per } \\
\text { unit area in Toronto area tributaries [9] }\end{array}$} & \multirow[b]{2}{*}{210 ng/g [4] } & $\begin{array}{c}222 \text { ng/g [1] } \\
\text { ND-560 ng/g [4] }\end{array}$ \\
\hline & & & $\begin{array}{c}\text { Mean: } 207 \mathrm{ng} / \mathrm{g} \text { wet } \\
(140 \text { - 240; } \mathrm{n}=3 \text { composites of 5) } \\
\text { spottail shiners; mean: } 186 \mathrm{ng} / \mathrm{g} \text { wet } \\
(160 \text { - 220: } \mathrm{n}=5 \text { composites of 5) } \\
\text { common shiners collected } \\
\text { in } 2000 \text { (OMOE, unpublished) }\end{array}$ \\
\hline $\begin{array}{l}\text { Twelve-Mile Creek, } \\
\text { St. Catharines ON }\end{array}$ & $\begin{array}{c}\text { Mean } 6.2 \mathrm{ng} / \mathrm{L} \\
(2.4-12.3, \mathrm{n}=12) \\
\text { ng/L-event grabs [6] } \\
\text { Mean } 1.1 \mathrm{ng} / \mathrm{L} \\
\text { (ND-2.3 } \mathrm{ng} / \mathrm{L}, \mathrm{n}=13) 28 \text { day } \\
\text { composite (OMOE unpublished) }\end{array}$ & $\begin{array}{l}950 \mathrm{ng} / \mathrm{g}[4] \\
650 \mathrm{ng} / \mathrm{g}[5]\end{array}$ & $\begin{array}{c}\text { Mean } 103 \mathrm{ng} / \mathrm{g} \text { wet } \\
\text { (160 - 220, } \mathrm{n}=5 \text { composites of 5) } \\
\text { (spottail shiners) } \\
\text { Mean } 430 \mathrm{ng} / \mathrm{g} \text { wet } \\
\text { (620 - 800, } \mathrm{n}=3 \text { composites of } 5) \\
\text { (emerald shiners) } \\
\text { (OMOE } 2001 \text { unpublished) }\end{array}$ \\
\hline $\begin{array}{c}\text { Twelve Mile Creek-Lake } \\
\text { Gibson/Beaverdams Creek, } \\
\text { Thorold, } \mathrm{ON}^{1}\end{array}$ & $\begin{array}{c}\text { Mean } 7.8 \mathrm{ng} / \mathrm{L} \\
(1.8-13.8, \mathrm{n}=3 \text { ) } \\
\text { Large volume grab samples } \\
\text { (OMOE unpublished, 2002) }\end{array}$ & $\begin{array}{l}\text { Consultant report }^{2} \\
\text { documented } \\
\text { concentrations } \\
\text { exceeding } 20 \mathrm{ug} / \mathrm{g}\end{array}$ & $\begin{array}{c}452 \text { - } 724 \text { ng/g wet } \\
\text { (OMOE } 2002 \text { unpublished) }\end{array}$ \\
\hline $\begin{array}{l}\text { Turkey Creek, } \\
\text { Windsor ON }\end{array}$ & $\begin{array}{c}\text { Mean } 2.43 \mathrm{ng} / \mathrm{L} \\
(0.2-8.7, \mathrm{n}=15) \\
28 \text { day time composite large volume } \\
\text { (OMOE unpublished, 2002) }\end{array}$ & 780 ng/g [7] & $\begin{array}{c}\text { Mean: } 216 \text { ng/g wet } \\
\text { (range } 180 \text { - 260)-1998 Emerald } \\
\text { shiners near tributary mouth; } \\
\text { Mean:123 ng/g wet } \\
\text { (100 - 280, n = } 5 \text { composites of 5) } \\
2001 \text { near tributary mouth } \\
\text { (OMOE unpublished) }\end{array}$ \\
\hline $\begin{array}{l}\text { Little River, } \\
\text { Windsor ON }\end{array}$ & $\begin{array}{c}\text { Mean } 1.7 \mathrm{ng} / \mathrm{L} \\
(0.6-3.8, \mathrm{n}=6) \\
28 \text { day time composite } \\
\text { large volume } \\
\text { (OMOE unpublished, 2002) }\end{array}$ & 1400 ng/g [7] & $\begin{array}{c}\text { Mean: } 92 \mathrm{ng} / \mathrm{g} \text { wet } \\
\text { (120 - 240, } \mathrm{n}=5 \text { composites of 5) } \\
2001 \text { spottail shiner data } \\
\text { near mouth (OMOE unpublished) }\end{array}$ \\
\hline
\end{tabular}

${ }^{1}$ Decision to pursue track down based on other available data (e.g. consultant reports, area history, environmental litigation etc.); ${ }^{2}$ Information not available for public release.

were identified by both the Lake Erie and Lake Ontario Lakewide Management Plans as lakewide critical pollutants.

Project Trackdown identified three specific objectives: 1 ) to identify locally controllable PCB sources if they exist; 2) to assess the effectiveness of various investigative tools in expediting source identification; and 3) to develop appropriate project designs and methods for future trackdown activities. This paper summarizes and evaluates the approaches used in identifying sources of PCBs to the environment. It also provides qualitative environmental triggers that can be used to differentiate between discrete sources of PCBs to the environment from the "noise" of non-specific PCB contamination typical of urban environments.

\section{Overview of Trackdown Approach}

A complete trackdown study comprises four separate stages of activity including (1) project planning, where appropriate tools are selected to maximize the likelihood of identifying source(s) using various lines of evidence, (2) scientific investigations focused on continually narrowing the geographical scope of the investigation by discounting non-source areas from potential source areas, (3) abatement of the source with possible remediation 
of the contamination by engaging any existing responsible parties towards abatement and/or remediation actions and (4) subsequent monitoring for improvements. The ultimate goal is to mitigate or eliminate ongoing and/or locally controllable sources of PCB contamination. We defined "ongoing" as the release of these contaminants in media (e.g. sediment, soils) such that potential for continued or re-introduced aquatic exposure exists; we define "locally controllable sources" as sources that can be mitigated by complete removal or separation from recontaminating the watershed.

\subsection{Techniques in Source Identification}

Several lines of evidence may be used in tracking contaminant sources. These are used to determine (a) if concentrations exceed background levels and (b) if these contaminants are biologically relevant as determined by uptake in resident biota. Source identification media may include sediment and event-based water sampling, biota collections (fish, invertebrates), deployment and analysis of caged biota (mussels) and integrated passive samplers, and in some cases soil sampling (e.g. creek bank soils). These media offer various advantages from screening-level (broad scale) to higher-resolution (local scale) identification of locally controllable sources. Broad scale assessments that identify tributaries with higher PCB loads for prospective trackdown studies have been conducted in the Great Lakes for sediment [5] [7], fish [1] and large-volume time-integrated water sampling [6]. Local scale source identifications have included enhanced sampling in these and other media (e.g. soils), as well as deployed biota or passive sampling media, and rain event-based water sampling.

Each technique has advantages and disadvantages; a combination of these allows the investigators to efficiently reduce the area of investigation and to assess contamination. Using several sampling media to substantiate results can provide a strong weight-of-evidence for source identification and the required justification for abatement and remediation activities. Although original guidance for the program recommended a tiered approach to source tracking that used only one or two media at a time [4], restricting initial sampling to only one or two media in sequence resulted in drawn-out studies that took years to complete. While the tiered approach may allow for a more strategic sampling program (more cost effective), experience in the pilot watersheds showed that using multiple lines of evidence concurrently in the same areas within the same sampling season resulted in more expedient source determination; having the same suite of sampling media at all sites allows for a more expeditious site prioritization and has been our preferred approach since it can narrow the search by eliminating sites as well as flagging anomalies.

1) Sediment sampling

Sediment sampling is a relatively easy and low-cost method for trackdown investigations; it works well as a screening tool in initial stages of an investigation. Depositional areas are targeted in selected reaches throughout each watershed, with an aim to reduce the geographical area of interest. Based on sampling methodology developed by the United States Geological Services [12] and adapted by Environment Canada [5] [7], our technique has been to sample depositional sediments in the smaller tributaries prior to discharge into the main branch of each river. Fine surficial sediments representing recent deposition are targeted to maximize the probability of detecting existing PCB contamination.

Sediment sampling is an effective method to narrow the project scope, but the elucidation of sources may be difficult using sediment information alone [4]. Fine sediments do not always accumulate in locations of interest, and clean sediment can dilute contamination and result in significant variability in the field. In addition, hydrologic characteristics of the system may result in contaminant deposition far downstream from the source [13] [14], or the mobilization of historically contaminated sediment during storm events that do not relate to ongoing sources. Therefore sediment sampling may not always detect a source if one exists; however, concentrations above background in sediment do provide a line of evidence to indicate a potential contaminant source upstream.

Confirmation of elevated PCB concentrations should be sought from at least one other medium. For example, juvenile forage fish, ideally, young-of-year (YOY) are a useful complement to sediment sampling to narrow the scope of investigation among river reaches and to assess potential bioavailability of PCB as evidenced by uptake in fish tissue. Additional information from fish tissue or semi-permeable membrane devices (SPMDs) helps separate priority areas (elevated levels in fish tissue and SPMDs) from those where PCBs detected in sediment are not considered bioavailable (low levels in fish tissue and SPMDs).

In addition to PCBs, organic carbon content and grain size are also assessed as they are important determinants of potential bioavailability and toxic effects of PCBs and other contaminants [15]. 
In later site-specific stages of investigation, sediment coring can be used to delineate the extent and depth of contamination, and to assess the potential for remobilization. Assessment of sediment toxicity and biota sediment accumulation factors (BSAFs) may also be important components for justifying abatement and remediation. As per Fletcher et al. [15], once a site is identified, a weight of evidence approach considering sediment chemistry, sediment toxicity, benthic community, and potential for biomagnification would be evaluated following an Ecological Risk Assessment framework to determine if remediation or other sediment management is required. These stages are implemented beyond the trackdown as part of the work of responsible parties.

2) Deployment and/or sampling of biota (fish, caged mussels and benthic invertebrates)

Biological uptake is a critical consideration in source tracking. Ultimately, the need for remediation depends on whether the contamination is bioavailable to resident biota, and potentially to the food chain. Areas in which biological uptake is evident are prioritized over those where contamination does not appear to be evident in organisms [15].

Biological uptake is assessed by the measurement of concentrations in biological tissues, caught in-situ (e.g., YOY forage fish or sport fish, benthic invertebrates) or deployed biomonitors (caged mussels), or their surrogates (passive samplers).

Assessing tissue PCB concentrations in endemic organisms such as YOY forage fish has proven highly useful in narrowing the geographical scope of investigations and determining the bioavailability of PCBs in the field. YOY forage fish have several attributes that make them well suited to trackdown studies. Their range of movement is relatively limited, so their tissue concentrations reflect localized bioavailability, and they represent a useful integration of spatial and temporal changes in water quality and exposure from consuming prey organisms [1] [16]. In addition, since their exposure is limited to what has occurred within the course of their lifetime (i.e. less than one year), YOY fish tissue concentration data provide an excellent measure of recent exposure and results are not confounded by variable exposure that may occur in older, more mobile fish. From a practical assessment perspective, tissue concentrations in fish can be compared against the International Joint Commission's (IJC) $100 \mathrm{ng} / \mathrm{g}$ dry weight (dw) tissue PCB guideline for the protection of wildlife consumers of fish [17].

Elevated PCB concentrations in sport fish have been used as a line of evidence in selecting priority watersheds for trackdown studies as many of the fish consumption advisories in the Great Lakes are attributed to PCBs [18]. Data on PCB concentrations in resident sport fish can also be useful within risk assessments in addressing area-wide contamination and prioritizing abatement actions that may relate to biomonitoring and meeting human health based fish consumption advisories [19]. However, their size and range make them less suitable for source-tracking purposes.

Caged organisms (usually mussels-Elliptio complanata, 6.5 to $7.2 \mathrm{~cm}$ long) are sourced from a relatively uncontaminated lake and typically deployed just above (i.e. not in contact with) stream sediments, and left in-situ for a period of 21 - 28 days. Upon retrieval, their tissues are processed and analysed for PCBs. Caged mussels are useful in trackdown studies because their tissue concentrations represent PCB uptake that is limited to a particular site, and is controlled by the duration of exposure. Thus, differences between sites can be quantitatively assessed using this technique (Figure 2).

Tissue PCB concentrations in caged mussels must be compared against reference conditions since there is no guideline for acceptable accumulation in deployed organisms. The study design must therefore include one or more deployments at an upstream (unimpacted) reference station at the same time.

Caged organisms are not ideal for use in situations where other contaminants (such as heavy metals) or degraded water quality conditions (such as low oxygen levels) may impede their normal biological function and potentially interfere with PCB uptake. Because priority locations for trackdown studies tend to have multiplecontaminants present, we have increasingly shifted to the use of abiotic passive samplers for assessing potential bioavailability.

On a highly localized scale, benthic invertebrates have been used to assess bioavailable PCB contamination as their body burdens reflect uptake to the food web (Figure 3). However, benthic invertebrate tissue residues are not a reliable initial screening tool because habitat degradation has left the benthic populations considerably impaired at many of the study sites, making it difficult to collect sufficient biomass for laboratory PCB analysis. In addition, species differences between sites may confound comparisons of benthic invertebrate PCB concentrations.

3) Event-based water sampling

Contaminants such as PCBs can be difficult to detect in water and require either low-level analyses or large 


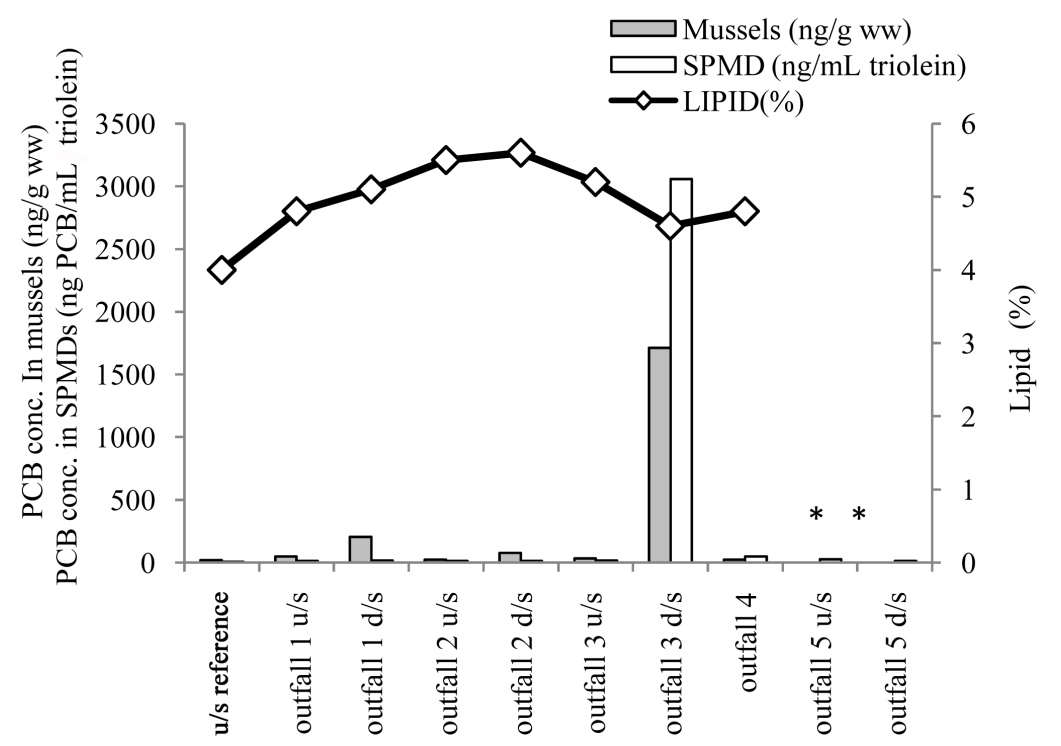

Figure 2. Caged mussels used in parallel with SPMDs in 2002 to identify potential sourcesat outfalls in Etobicoke Creek, Toronto, Ontario. Cages were placed upstream and downstream of suspected sources and compared against an upstream watershed reference location. Mussel collection, deployment and retrieval methods are as described in [20] with the following exceptions: deployment occurred over 28 days in the trackdown study for comparison to SPMD uptake; composites of 10 - 12 mussels (up to $80 \mathrm{~g}$ wet tissue) were used for PCB and lipid content analysis. (u/s = upstream, $\mathrm{d} / \mathrm{s}=$ downstream). PCB concentrations in SPMDs are averages of three deployed strips (ng PCB/mL triolein). Mussel and SPMD uptake results were used along with other media to follow-up on a nearby source entering the creek. ${ }^{*}$ No samples: Mussels did not survive the deployment period at two locations (outfall $5 \mathrm{u} / \mathrm{s}$ and $\mathrm{d} / \mathrm{s}$ ).

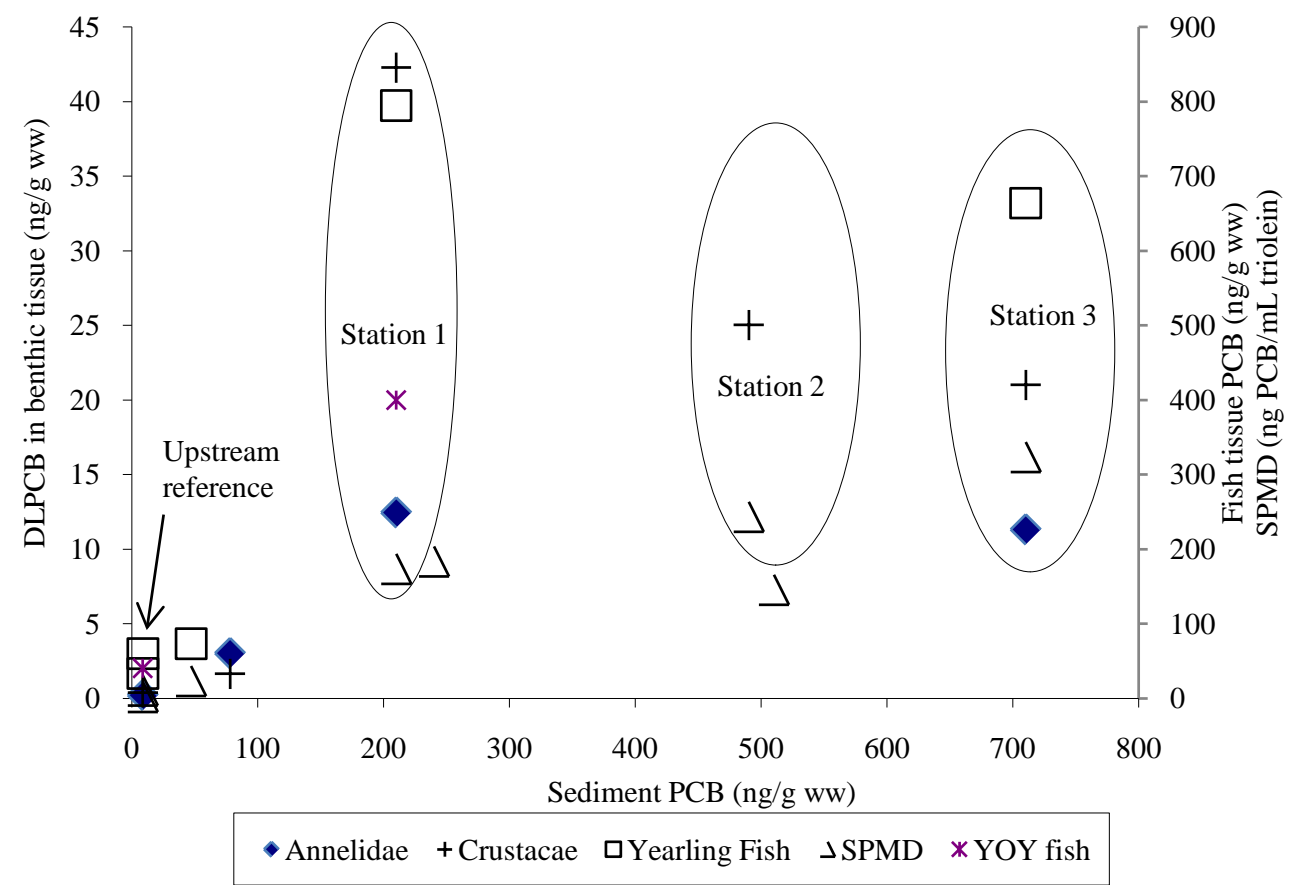

Figure 3. Dioxin-like PCB tissue burdens (ng/g WW) in benthic invertebrates (Annelidae, Crustacea) used in conjunction with other biota (fish: total PCB ng/g ww) and SPMDs (Total PCBs ng/mL triolein) in relation to concentrations in sediment in the Cataraqui River Inner Harbour, Kingston Ontario. Three locations of interest were identified (circled) as potential sources of biologically available PCBs [21]. Subsequent source tracking led to a local hotspot and removal of sediment at station 1 in 2005 through the Emma Martin Park Sediment Remediation project [22] [23]. Only dioxin-like PCBs were analysed in the benthic invertebrate data due to limited biomass availability. 
volumes of water. Prior to the development of appropriate methods with sub-ng/L detection limits, large volume (19 L), time-integrated samples were collected at the mouths of tributaries to identify watersheds requiring further investigation [6]. However this approach became unsustainable when event-based sampling required several stations to be sampled concurrently within the watersheds.

Substantial efforts were needed for cleaning equipment, samples were heavy and difficult to transport in large quantities, and laboratory extraction processes were lengthy for such large volumes. Improved laboratory methods have allowed us to reduce sample volumes to manage event-based water sampling, as detailed below.

PCBs are typically more prevalent during runoff conditions in urban environments as they are hydrophobic compounds often associated with suspended particulate matter [9]. Therefore, we focused on water sampling during rain events to maximize the likelihood of PCB detection. We sampled a minimum of three rain-events to confirm the consistency of PCB contamination. In addition, although detections during baseflow conditions are less substantial, baseflow sampling is an important component that should be included in the trackdown program as it can be diagnostic in some situations where sources are more prevalent during baseflow, and where surface run-off has a diluting effect.

In order to clearly distinguish "rain events" from "baseflow conditions" we arbitrarily defined the former as $10 \mathrm{~mm}$ of rain within 24 hours, and the latter as an absence of rain within the previous 48 hours. Note that larger catchments may require a longer time for conditions to return to baseflow.

Total suspended solids (TSS) are routinely analysed to assess the relationship of PCBs with suspended particulates. Because PCBs are strongly sorbed to solids, the relationship can be helpful to indicate the source of the contamination. For example, intermittent pulses that are not associated with the sediment burden can indicate a labile, unbound source, whereas PCBs primarily associated with suspended solids might indicate historic sediment or soil contamination.

In a recent trackdown follow-up study [24], knowledge of hydrographical conditions (timing of rain event, gauged flow levels, stage discharge curves and associated inputs of suspended sediments) proved crucial in differentiating the delivery of PCBs from two potential sources that were tracked down to one outfall of interest located downstream of a former landfill (Figure 4). Homologue patterns were shown to change with time after a rain event, with lighter (less chlorinated) congeners evident in seepage, and heavier (more chlorinated) congeners associated with runoff and elevated suspended sediments (Figure 5).

Event based water sampling is limited in that it only represents a snap-shot of conditions at the time of sampling, may not always capture concentrations indicating a potential source, and may not reflect long term conditions. Low (or non-detect) concentrations cannot be used solely to rule out the existence of a potential source. However, sampling on various occasions allows us to identify with some consistency, a range of conditions that may exist. Used in conjunction with other lines of evidence that provide more integrated evidence of exposure, event-based water sampling is an important and useful diagnostic component of our investigations.

4) Integrative passive sampling techniques

The use of integrative passive samplers such as SPMDs has greatly improved our ability to conduct trackdown investigations. SPMDs consist of thin-walled polyethylene strips containing a synthetic lipid such as triolein [25]. When deployed in an aquatic environment, hydrophobic organic contaminants such as PCBs diffuse into SPMDs and accumulate. SPMDs are deployed at locations selected to maximize the potential for source identification (i.e. downstream of, or within waterways and outfalls). The deployment of SPMDs in water over a specific period of time (usually 28 days) allows for the measurement of hydrophobic organic compounds such as PCBs and helps approximate the biological uptake of these contaminants into lipid layers of organisms such as fish and caged mussels. The use of SPMDs is advantageous over deployed organisms (i.e. caged mussels), because SPMDs are insensitive to environmental factors such as high trace metal content or low oxygen levels that may be adverse to organisms.

SPMDs may, however, be subject to fouling from algal growth or sedimentation, which may influence uptake, or they may become exposed to air in shallow waters. In addition, differences in temperature and water flow between deployment sites may influence the uptake of contaminants. However, a variance of within $10^{\circ} \mathrm{C}$ appears to be insignificant to uptake in SPMDs [26] [27].

While SPMDs can be used to calculate PCB concentrations in water using performance reference compounds [28], we use the information qualitatively to compare concentrations and congener patterns between sites. We've used SPMDs as an indicator of biological availability, such that the greater the uptake of PCBs in the SPMDs, the more likely PCBs are to be available to organisms at the location tested, or the closer the source of 


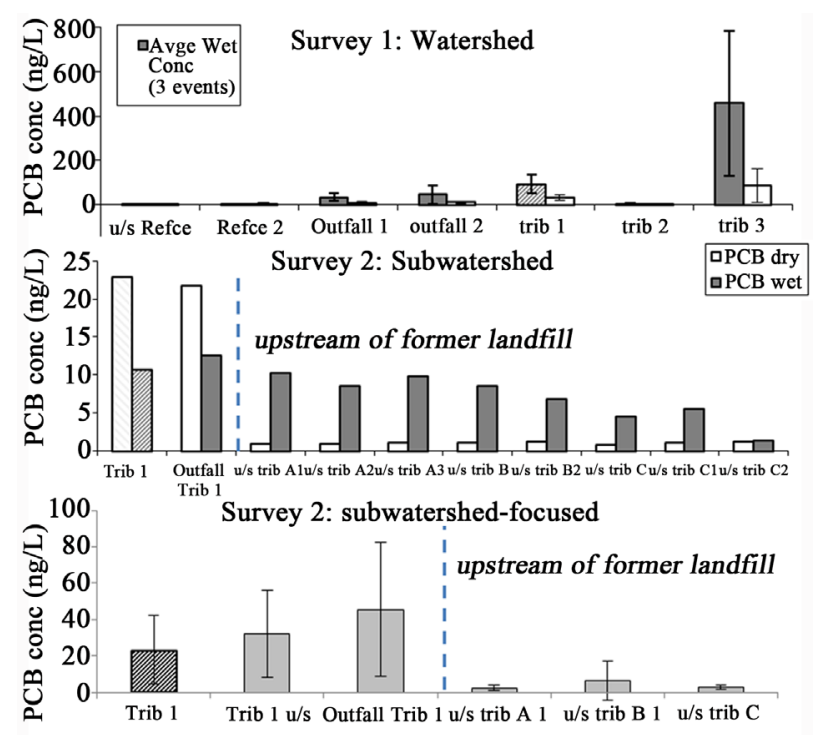

Figure 4. Water sampling in a section of the Twelve-Mile Creek Watershed (St. Catharines, Ontario). Only PCB concentrations are depicted herein. Other analyses included suspended solids [24]. Top: Average wet $(\mathrm{N}=3)$ and dry $(\mathrm{N}=3)$ concentrations at major inputs into the watershed. Error bars represent standard deviations. Flows measurements at Trib 1 (thatched bars) suggested a potentially greater load of contaminants than Trib 3 due to catchment size, and was the subject of further investigation. Middle: Survey of Trib 1 and its upstream tributaries: concentrations of PCBs sampled in one dry and one wet event. Congener patterns suggested different PCB inputs (lighter congener profiles) in higher dry-event concentrations downstream of a former landfill (Outfall Trib 1) compared to wet event samples. Bottom: Survey 3 focused the investigation on inputs upstream and downstream of former landfill. Four events were sampled to capture a range of flow conditions $(\mathrm{N}=$ 4); error bars represent standard deviations. Concentrations and congener patterns from Outfall Trib 1 were further analysed to determine differences in PCB homologue patterns as seen in Figure 5.

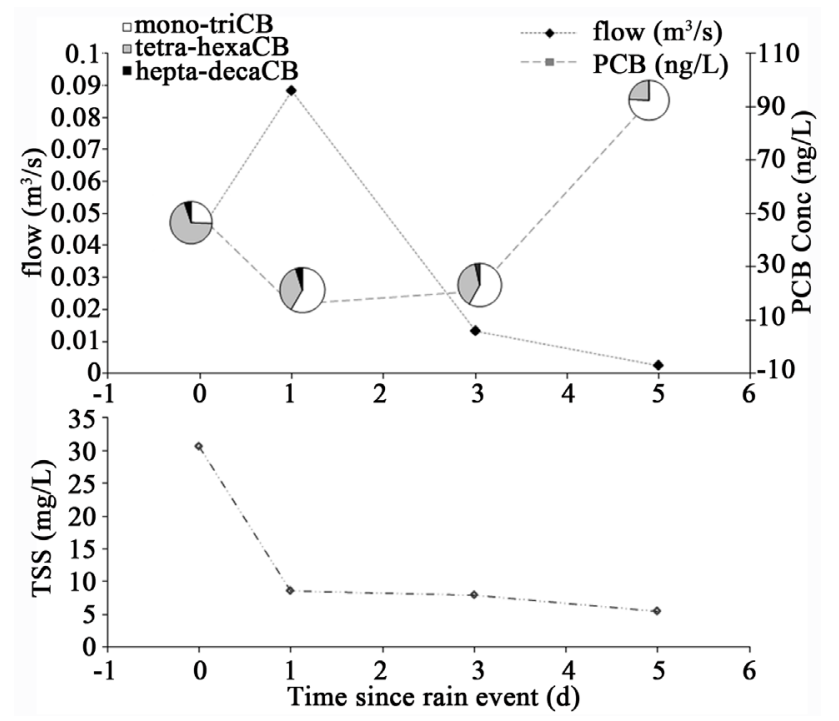

Figure 5. Top: Flow and PCB concentration by discrete sampling event at an outfall in the Twelve-Mile Creek Watershed, where suspected sources include a former landfill and runoff from potentially contaminated soils [24]. Data points are ordered by delay (number of days) since a rain event. Flow $\left(\mathrm{m}^{3} / \mathrm{s}\right)$ was determined using spot discharge measurements during each water sampling event to examine a range of conditions at the location of interest. Precipitation events were recorded from a nearby Environment Canada gauge station. Homologue proportions (pie charts) are juxtaposed on total PCB concentrations (ng/L, right vertical axis) Bottom: suspended solids by sampling event. X axis represents number of days after a significant $(>10 \mathrm{~mm}$ ) rain event. Day 0 represents a sample collection at the onset of a precipitation event. Results allowed investigators to suggest a link between the changes in homologue patterns and the amount of suspended solids in the receptor waterway. 
contamination (e.g. Figure 2). Consequently, differences in concentrations and congener patterns of PCBs between locations have been extremely useful in identifying sources [29]. Water and/or other media can then be used to provide the trigger-based concentrations required for subsequent compliance-based assessments as detailed later in this document. Although SPMDs reflect dissolved-phase PCBs (i.e., they bias towards lower chlorinated congeners), Project Trackdown's efficacy lies in using various lines of evidence to confirm a suspected source, and we have not found this bias to be problematic.

Although every effort is made to keep SPMDs within the water column, the water depth at some of the sampling locations precluded complete separation from the sediment bed. However, this has sometimes worked to our advantage, as SPMDs have been useful in making the link between congener patterns in sediment and water column contamination (Figure 6), and in indicating the continued release of bioavailable PCB porewater contamination where other factors (e.g. lack of oxygen) have precluded the collection of fish for analysis [30]. Combined with in-situ sampling of YOY forage fish where available, SPMDs provide a useful line of evidence in delineating contamination and identifying potential for exposure.

5) Soils

Soil sampling has generally been conducted when riverbank erosion has been identified as a potential pathway of contamination to the waterway. In two studies, it was demonstrated that the controllable source of PCB contamination was eroding from river banks in the form of side-cast material from previous sediment dredging projects or contaminated fill material along engineered easements, thereby linking on-land contamination to increased PCBs in the waterways [30] [31].

\section{Options for PCB Analysis and Data Interpretation}

For all environmental matrices, laboratory analysis of PCBs can be conducted using Aroclor-based methods or congener-specific methods. Methods that analyse for commercial mixtures of PCBs (Aroclors) provide a practical and economical approach for quantifying PCBs from a compliance perspective. However, Aroclor-based methods limit our ability to interpret mixtures of PCBs in the environment, and may underestimate actual concentrations. Reference standards for Aroclors do not necessarily capture degraded PCBs that contain non-Aroclor congeners [32], and their use may lead to erroneous quantification of Aroclors that are not necessarily attributed to the source of contamination [33].

For any medium, detection limits must be suited to differentiate background concentrations from potential sources. Note that background concentrations used within this paper do not represent "natural” PCB concentrations found in the absence of anthropogenic contamination, but rather reflect "typical” concentrations in the urban environment in the absence of known sources of PCBs.

Selection of an appropriate detection limit is particularly relevant to water in which most urban background concentrations (<10 ng/L) fall below detection limits using Aroclor-based methods (50 - 200 ng/L) (Table 2). Because PCBs are hydrophobic, they partition primarily in sediment and biota and low concentrations are typically found in the surface water. Because PCBs bioaccumulate within the tissues of organisms and biomagnifyin the food chain, being able to differentiate between background and potential anomalies in water is environmentally relevant for trackdown studies.

In 2004, the OMOE developed a congener-specific PCB analysis method for water that provides low detection limits ( $<1 \mathrm{ng} / \mathrm{L}$ for a 1 - $2 \mathrm{~L}$ sample) using high resolution mass spectrometry [34]. The method includes up to 82 congeners most commonly found in water, biota and sediment [32], including the European list of 7 [35], and those with potential toxic effects (i.e. dioxin-like PCBs), as well as congeners found in Aroclor mixtures at greater than $0.5 \%$ [36]. Although the method analyzes 82 of 209 congeners, the contribution of the remaining 117 possible congeners is between 5\% and 10\%, however, in practice most of these congeners are not detected and the bias is negligible [37]. Water samples collected for Project Trackdown were largely analysed using this method.

In the simplest of assessments, areas of consistently high concentrations in several media are used to point to a source. This form of assessment using concentrations and relative differences between sites results in the quickest sourcing of contamination. However, as is the case in many urban areas, multiple sources may contribute to contamination.

In a second tier of assessment, homologues or congener patterns can be compared for similarities in "fingerprints” between sites, and hence congener-specific methods have become preferred for trackdown projects. 

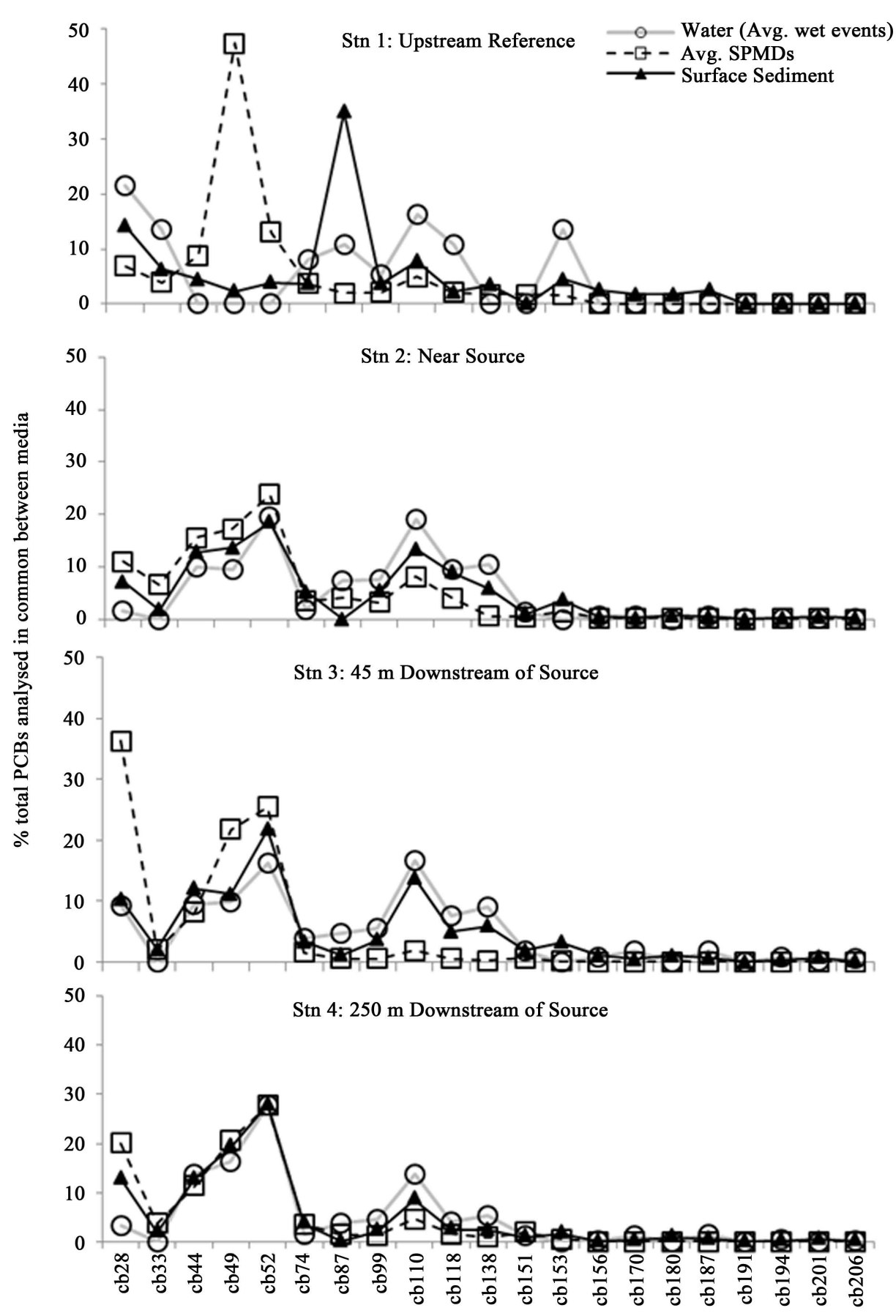

Figure 6. Example where SPMDs (squares) were plotted to look at similarities between contaminated sediment (triangles) and water (circles) using congeners analysed in common between media in four locations (from top: Stn 1: upstream Reference; Stn 2: Near source; Stn 3: 45 m downstream; Stn 4: 250 m downstream of source) in the Twelve-Mile Creek/Beaverdams Creek Watershed in 2003 and 2004 (OMOE, 2004 internal report). Bottom axis represents IUPAC numbers for each of the congeners listed. Data are shown as plotted lines to facilitate pattern visualization. Concentrations at stations 2, 3, and 4 exceeded Trackdown trigger values for both sediment and water. Concentrations in surface sediment were as follows: Stn 1: 29 ng/g; Stn 2: 2400 ng/g; Stn 3: 310 ng/g; Stn 4: 2100 ng/g. Average (range in parentheses) wet weather water concentrations were as follows: Stn 1: $0.3 \mathrm{ng} / \mathrm{L}(0$ - 0.9); Stn 2: $100 \mathrm{ng} / \mathrm{L}$ (2.6 - 390); Stn 3: $18.6 \mathrm{ng} / \mathrm{L}$ (2.3 - 36.9); Stn $413.1 \mathrm{ng} / \mathrm{L}$ (0 35.8). Biota were not viable for this study. Elevated PCB concentrations at Stn 2 and downstream pattern similarities prompted orders against a company to delineate contamination. PCB contamination was attributed to the use of recycled carbonless copy paper in stock material at an adjacent site. 
Table 2. PCB concentrations in water found at various trackdown locations with background conditions. Data represent samples taken from 2004-2010 using OMOE’s congener specific PCB method (Detection limit < 1 ng/L) [34]. Sites labeled as "reference" were selected a-priori. "Non-source" sites refer to locations initially selected for source trackdown that were discounted from further tracking due to lack of evidence of an existing source.

\begin{tabular}{|c|c|c|c|c|c|c|c|c|c|}
\hline \multirow[b]{2}{*}{ Watershed } & \multirow[b]{2}{*}{$\begin{array}{l}\text { Location } \\
\text { type }\end{array}$} & \multicolumn{4}{|c|}{ Wet events } & \multicolumn{4}{|c|}{ Dry events } \\
\hline & & $\begin{array}{l}\text { Average } \\
\text { (range) } \\
\text { PCB (ng/L) }\end{array}$ & $\begin{array}{l}\text { Median } \\
\text { PCB } \\
(\mathrm{ng} / \mathrm{L})\end{array}$ & $\begin{array}{l}\text { Range } \\
\text { susp. } \\
\text { solids } \\
(\mathrm{mg} / \mathrm{L})\end{array}$ & $\begin{array}{c}\# \\
\text { Samples }\end{array}$ & $\begin{array}{c}\text { Average } \\
\text { (range) } \\
\text { PCB } \\
\text { (ng/L) }\end{array}$ & $\begin{array}{l}\text { Median PCB } \\
\text { (ng/L) }\end{array}$ & $\begin{array}{c}\text { Range } \\
\text { suspended } \\
\text { solids } \\
\text { (mg/L) }\end{array}$ & $\begin{array}{c}\# \\
\text { Samples }\end{array}$ \\
\hline $\begin{array}{l}\text { Cataraqui River } \\
\text { (Kingston) }\end{array}$ & $\begin{array}{l}\text { Upstream } \\
\text { reference }\end{array}$ & $\mathrm{n} / \mathrm{a}$ & & & & 0.0 & & $4.8-17.9$ & 2 \\
\hline $\begin{array}{l}\text { Etobicoke Creek } \\
\text { (Toronto) }\end{array}$ & Non-source & $\begin{array}{c}7.4 \\
(1.8-22.4)\end{array}$ & 2.4 & $49-575$ & 4 & 1.1 & & 6.6 & 1 \\
\hline $\begin{array}{l}\text { Twelve-Mile Creek } \\
\text { (St. Catharines) }\end{array}$ & Non-source & $\begin{array}{c}9.5 \\
(1.5-22.4)\end{array}$ & 4.6 & 18.1 - 38.5 & 3 & $\begin{array}{c}2.0 \\
(0.8-3.9)\end{array}$ & 2.0 & $5-87$ & 9 \\
\hline \multirow{2}{*}{$\begin{array}{c}\text { Twelve-Mile } \\
\text { Creek-Beaverdams } \\
\text { Creek. (Thorold) }\end{array}$} & $\begin{array}{l}\text { Upstream } \\
\text { reference }\end{array}$ & $\begin{array}{c}3.1 \\
(1.2-5.8)\end{array}$ & 2.8 & $16.6-39.3$ & 4 & $\begin{array}{c}1.1 \\
(0.5-1.5)\end{array}$ & 1.1 & $3.1-51$ & 4 \\
\hline & Non-source & $\begin{array}{c}0.5 \\
(0.1-1.3)\end{array}$ & 0.1 & $6.4-8.7$ & 3 & 0.4 & & 4.5 & 1 \\
\hline $\begin{array}{l}\text { Walker's Creek (St. } \\
\text { Catharines) }\end{array}$ & $\begin{array}{l}\text { Urban } \\
\text { reference }\end{array}$ & $\begin{array}{c}2.6 \\
(0.6-6.2)\end{array}$ & 1.2 & $4.1-610$ & 3 & 0.7 & & 15.2 & 1 \\
\hline $\begin{array}{c}\text { Spring Garden } \\
\text { Creek (St. Catharines) }\end{array}$ & $\begin{array}{l}\text { Urban } \\
\text { reference }\end{array}$ & $\begin{array}{c}2.1 \\
(0.5-4.0)\end{array}$ & 1.6 & $4.1-80.1$ & 3 & 0.2 & & 5.8 & 1 \\
\hline \multirow{2}{*}{$\begin{array}{l}\text { Turkey Creek } \\
\text { (Windsor) }\end{array}$} & $\begin{array}{l}\text { Upstream } \\
\text { reference }\end{array}$ & $\begin{array}{c}1.0 \\
(0.1-1.9)\end{array}$ & 1.1 & $1.7-46.5$ & 4 & $\begin{array}{c}1.1 \\
(0.1-3.7)\end{array}$ & 0.3 & $5.7-27.8$ & 4 \\
\hline & Non-source & $\begin{array}{c}5.2 \\
(0.3-18.1)\end{array}$ & 2.4 & 5.5 - 118 & 10 & $\begin{array}{c}4.5 \\
(0.1-27.8)\end{array}$ & 0.6 & $2.8-858$ & 13 \\
\hline \multirow{2}{*}{$\begin{array}{l}\text { Little River } \\
\text { (Windsor) }\end{array}$} & $\begin{array}{l}\text { Upstream } \\
\text { reference }\end{array}$ & $\begin{array}{c}5.8 \\
(1.2-10.4)\end{array}$ & $\mathrm{n} / \mathrm{a}$ & 47.6 - 400 & 2 & $\begin{array}{c}0.6 \\
(0.4-0.9)\end{array}$ & 0.4 & $13.4-21.0$ & 3 \\
\hline & Non-source & $\begin{array}{c}3.5 \\
(1.3-7.5)\end{array}$ & 3.3 & $46.2-131$ & 7 & $\begin{array}{c}1.8 \\
(0.8-3.8)\end{array}$ & 1.6 & $8.4-43.0$ & 7 \\
\hline
\end{tabular}

Congener-specific methods can differentiate between sources despite the influence of degradation and weathering of the original PCB mixtures. A comparison of congener profiles between sites can also provide an indication of whether the PCBs originate from a common source. Using congener-specific analysis allows flexibility in interpreting data both from an empirical perspective, and for statistical and visual "fingerprinting” [32]. The fingerprinting concept works best when comparing patterns among locations in the same medium because it avoids the issue of biotransformation and differential partitioning from water into sediment. In some cases, congeners analysed in common between media can be compared with relative ease (e.g., sediment, water, biota or SPMDs) to determine whether generally similar patterns of contamination occur (Figure 6), recognizing that patterns will change based on specific partitioning of PCB congeners, and potential biotransformation in biota [38]-[40].

Statistical mining or data reduction techniques such as principal component analysis (PCA) have proven useful in distinguishing differences in PCB patterns between sites that may not be seen in graphical comparisons of congener patterns [41] [42]. PCA has proven useful in uncovering a secondary source otherwise overwhelmed by a larger, more proximate source, and in identifying spatial patterns that may be obscured by temporal variability (Figure 7).

Despite these strengths, PCA and other data mining techniques may not always suffice for complex mixtures of degraded congeners. In these cases, other source apportionment techniques (e.g. PCA with non-negative constraints, receptor modeling, positive matrix factorization) may be warranted [41] [43]. Each matrix should be analysed separately, as patterns between media are not readily comparable with PCA.

\section{Decision-Making Using Weight-of-Evidence Approach}

In the initial phases of the trackdown project, it can be challenging to interpret the various lines of evidence, 


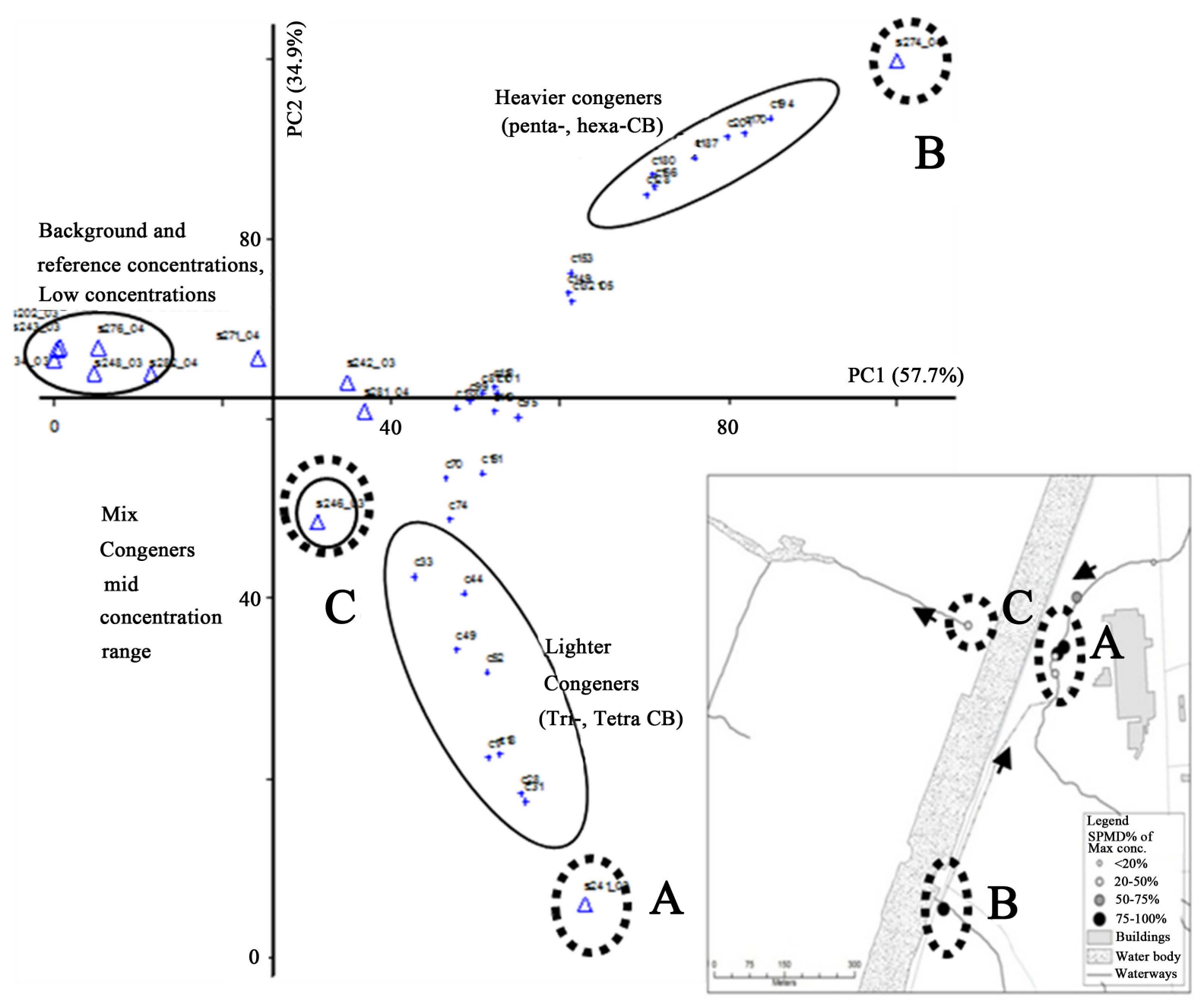

Figure 7. Example biplot of principal component analysis (PCA) on SPMD congener data from a study location of interest in the Twelve-Mile Creek/Beaverdams Creek watershed, Thorold, Ontario (OMOE, 2005 internal report). Congeners are represented by $(+)$ sign and adjacent IUPAC number (e.g. C74). SPMD deployment locations are depicted as triangles and station identification numbers (e.g. 241_03 = station 241 deployed in 2003). Congener patterns were compared as concentrations (ng PCB/mL triolein). Although overall concentrations differed between years 2003 and 2004 and accounted for much of the variability along the first principal component, differences in pattern were evident between sites. Congener patterns suggested a separate source dominated by heavier congeners at a site (B) upstream of main source contamination (A), contributing to downstream PCB patterns (C). Sources of contamination included carbonless copy paper and cutting oils used in manufacturing car parts. Inset: Map of locations of interest. Arrows show direction of water flow from upstream sources (A and $\mathrm{B}$ ) to the downstream receptor location (C).

especially when more than one source is suspected. Identifying and ranking sources is critical for prioritizing those that need to be addressed through abatement activities. Furthermore, due to the ubiquity of PCBs in urban environments, abatement activities necessarily need to focus on achieving the most value and overall benefit to the environment. In prioritizing efforts in a budget constrained climate, the following questions need to be addressed: What constitutes a relevant trigger concentration for each medium? Does contamination matter if it's not a biological "problem"? How do you prioritize what is considered to be a problem?

\subsection{What Constitutes a Relevant Trigger Concentration?}

\section{1) Sediment}

PCBs occur almost ubiquitously in fine, depositional stream sediments, particularly in urban environments where past industrial uses are likely [5] [7]. As part of Project Trackdown, we assessed concentrations relative to 
various Canadian sediment quality benchmarks, including the federal Canadian Council of Ministers of the Environment (CCME) sediment quality guidelines [44] and Ontario's Provincial Sediment Quality Guidelines (PSQG) [45]. For urban area trackdown studies, our findings from initial sediment screenings within the trackdown watersheds (Figure 8; Table 3) suggested that the CCME Probable effect level (PEL) of $277 \mathrm{ng} / \mathrm{g}$ is a reasonable trigger concentration above which further source tracking is warranted ([4] [44]); this concentration range is consistent with findings in other watersheds [46]. The PSQG lowest effect level (LEL) (70 ng/g) was not generally a useful threshold since it appeared to indicate general urban contamination that would be difficult to attribute to a particular source. The PEL trigger level needs to be taken in context with other lines of evidence noted in this paper, and within the context of the study area's overall level of contamination. Highly industrialized areas may require the selection of relevant reference conditions.

2) Water

Sampling for water is an integral component in trackdown assessments. However, determining trigger concentrations of PCBs in water samples initially presented a challenge. The federal CCME has withdrawn its water guideline for PCBs because biological exposure is predominantly via sediment, soil and/or tissue [4]. Given the ubiquity of PCBs in urban environments and the difficulty in differentiating between typical urban background concentrations and local anomalies, the challenge has been to define a value above which a significant nearby source is indicated. Based on the $100 \%$ frequency of detections exceeding provincial water quality objectives (PWQO) for PCB (>1 ng/L) [6] and from Toronto area large-volume water sampling programs, we initially set an arbitrary concentration of $10 \mathrm{ng} / \mathrm{L}$ PCB $(10 \times$ the PWQO) as a starting point to distinguish concentrations in

Table 3. Typical PCB concentrations found in non urban/reference areas and non-source urban areas in Ontario Trackdown studies. Data collected between 2000-2011 in watersheds identified in Figure 1.

\begin{tabular}{|c|c|c|}
\hline & Reference locations & Urban non-source areas \\
\hline & \multicolumn{2}{|c|}{ Water (ng/L) } \\
\hline Mean & 2.1 & 4.3 \\
\hline Median & 1.1 & 2.1 \\
\hline $90^{\text {th }}$ percentile & 4.0 & 11.0 \\
\hline Range & $0.0-17.4$ & $0.1-27.8$ \\
\hline \multirow[t]{2}{*}{$\mathrm{N}$} & 31 & 57 \\
\hline & \multicolumn{2}{|c|}{ Sediment (ng/g dw) } \\
\hline Mean & 10.3 & 80.5 \\
\hline Median $^{\mathrm{a}}$ & 10 & 44.4 \\
\hline $90^{\text {th }}$ percentile & 20 & 240.0 \\
\hline Range & ND-20 & ND-580 \\
\hline \multirow[t]{2}{*}{$\mathrm{N}$} & 9 & 79 \\
\hline & \multicolumn{2}{|c|}{ YOY forage fish (ng/g ww) ${ }^{\mathrm{b}}$} \\
\hline Mean & 41.7 & 69.4 \\
\hline Median $^{\mathrm{a}}$ & 27 & 62 \\
\hline $90^{\text {th }}$ percentile & 100 & 120 \\
\hline Range & ND-150 & ND-170 \\
\hline $\mathrm{N}$ & $48^{\mathrm{c}}$ & 93 \\
\hline
\end{tabular}

${ }^{\mathrm{a}}$ Non-detect samples were counted as detection limit (sediment: $10 \mathrm{ng} / \mathrm{g} \mathrm{dw}$; fish tissue: $20 \mathrm{ng} / \mathrm{g}$ ww) and included in calculations; ${ }^{\mathrm{b}}$ Fish tissue from various forage fish have been combined for reference purposes only. Interpret with caution. Fish species include common shiner (Luxiluscornutus), spottail shiner (Notropis hudsonius), emerald shiner ( $N$. atherinoides), sand shiner (N. stramineus), golden shiner (Notemigonus crysoleuca), creek chub (Semotilus atromaculatus), fathead minnow (Pimephales promelas), bluntnosed minnow (P. notatus), yellow perch (Perca flavescens), and goldfish (Carassius auratus). ${ }^{\mathrm{C}}$ Includes fish collected from reference area in Lake Erie (Turkey point). 


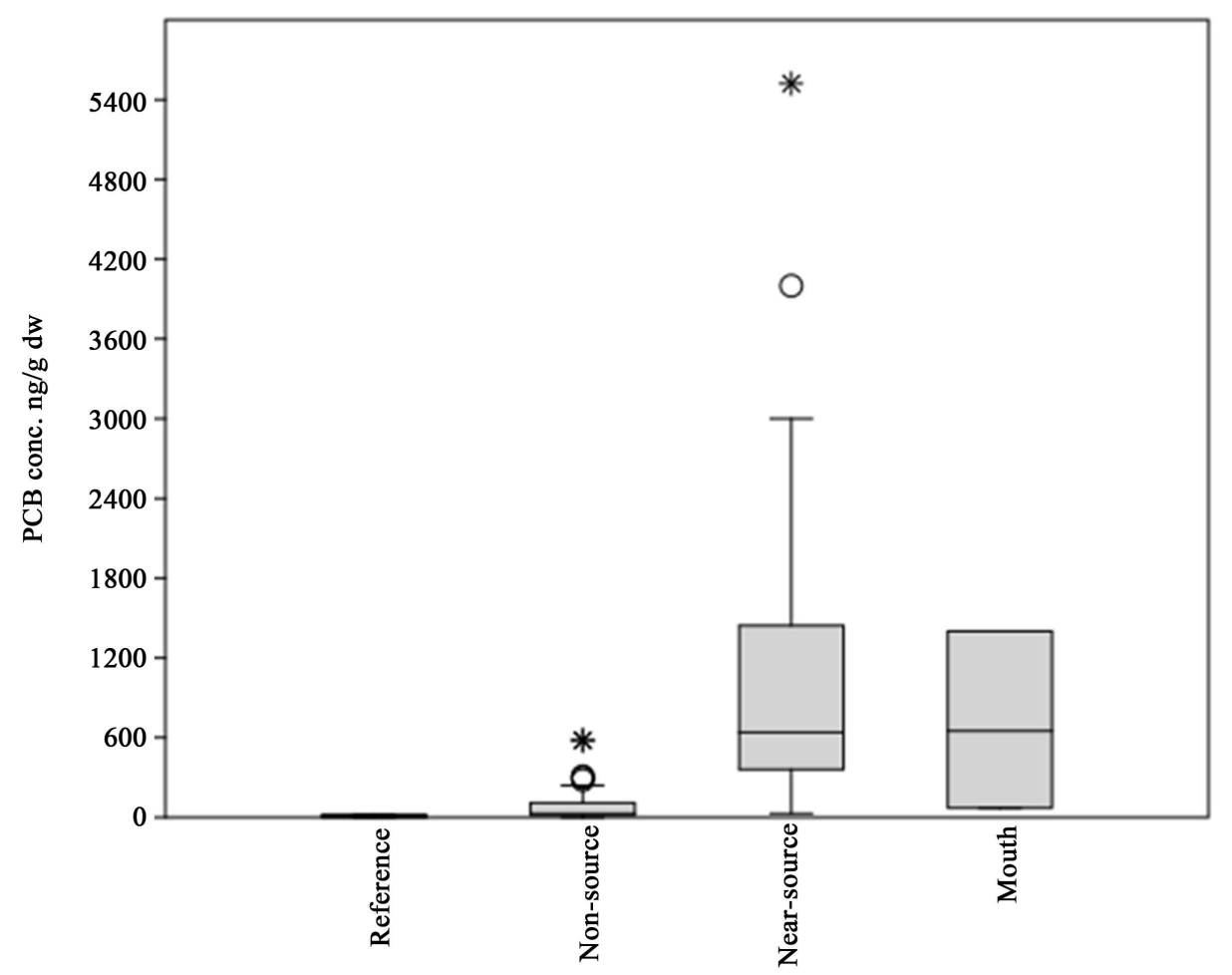

Figure 8. Box plot of median and range of PCB concentrations in sediment collected in the initial screening stage within the five watersheds of Project Trackdown. Bottom and top of boxes represent $25^{\text {th }}$ and $75^{\text {th }}$ percentiles respectively. Whiskers represent $10^{\text {th }}$ and $90^{\text {th }}$ percentiles. Outliers have been included. Reference locations were chosen a-priori; urban non-source sites were discounted from further trackdown; near source sites represent areas influenced by a nearby source; mouth values were concentrations found at the main tributary mouths.

streams that warranted follow-up. We hypothesized that concentrations of $<10 \mathrm{ng} / \mathrm{L}$ reflected ambient levels in urban waters. The testing of two urban creeks Spring Garden Creek and Walker's Creek in St. Catharines, ON, with no known PCB contamination as urban reference sites helped support this hypothesis (Table 2). Concentrations at most of the areas in our studies that did not show evidence of a PCB source were less than $10 \mathrm{ng} / \mathrm{L}$ (Table 3); however, it should be noted that concentrations exceeding $20 \mathrm{ng} / \mathrm{L}$ may occur, even in urban background (no ongoing sources) areas during highly turbid conditions following a significant rain event, often as a result of increased suspended solids loads (Table 2). Nevertheless, our experience has shown these conditions to be the exception rather than the norm (Table 3). Investigators need to exercise professional judgement and consider site-specific factors (e.g. industrialized areas) in establishing appropriate trigger levels for action.

3) Passive samplers

With passive samplers such as SPMDs, no appropriate trigger concentrations were applied in the context used for trackdown, as performance reference compounds were not used to determine equivalent water concentrations. However, concentrations can be compared relative to background conditions in each watershed as an indication of potential for PCB uptake.

4) Biota

The IJC tissue PCB guideline of $100 \mathrm{ng} / \mathrm{g}$ ww for the protection of consumers of fish [17] is a useful benchmark for biotic samples, above which further investigations are warranted. In the urban context, however, where the IJC guideline is often exceeded in YOY forage fish and consequently, a concentration of $200 \mathrm{ng} / \mathrm{g} \mathrm{ww}$ (i.e. twice the IJC guideline) provides a more practical trigger for indicating the potential presence of an ongoing source. The use of this adjusted benchmark for follow-up is illustrated in Etobicoke Creek, where concentrations exceeding $200 \mathrm{ng} / \mathrm{g} \mathrm{ww}$ were considered a more appropriate indicator of proximity to a nearby source of exposure (Figure 9). Findings from our watersheds have shown this benchmark to be appropriate for our purposes (Table 3). However, this trigger value may need to be adjusted upward in highly urbanized, industrial, or more contaminated areas where a more ubiquitous exposure may be difficult to distinguish from exposure from 


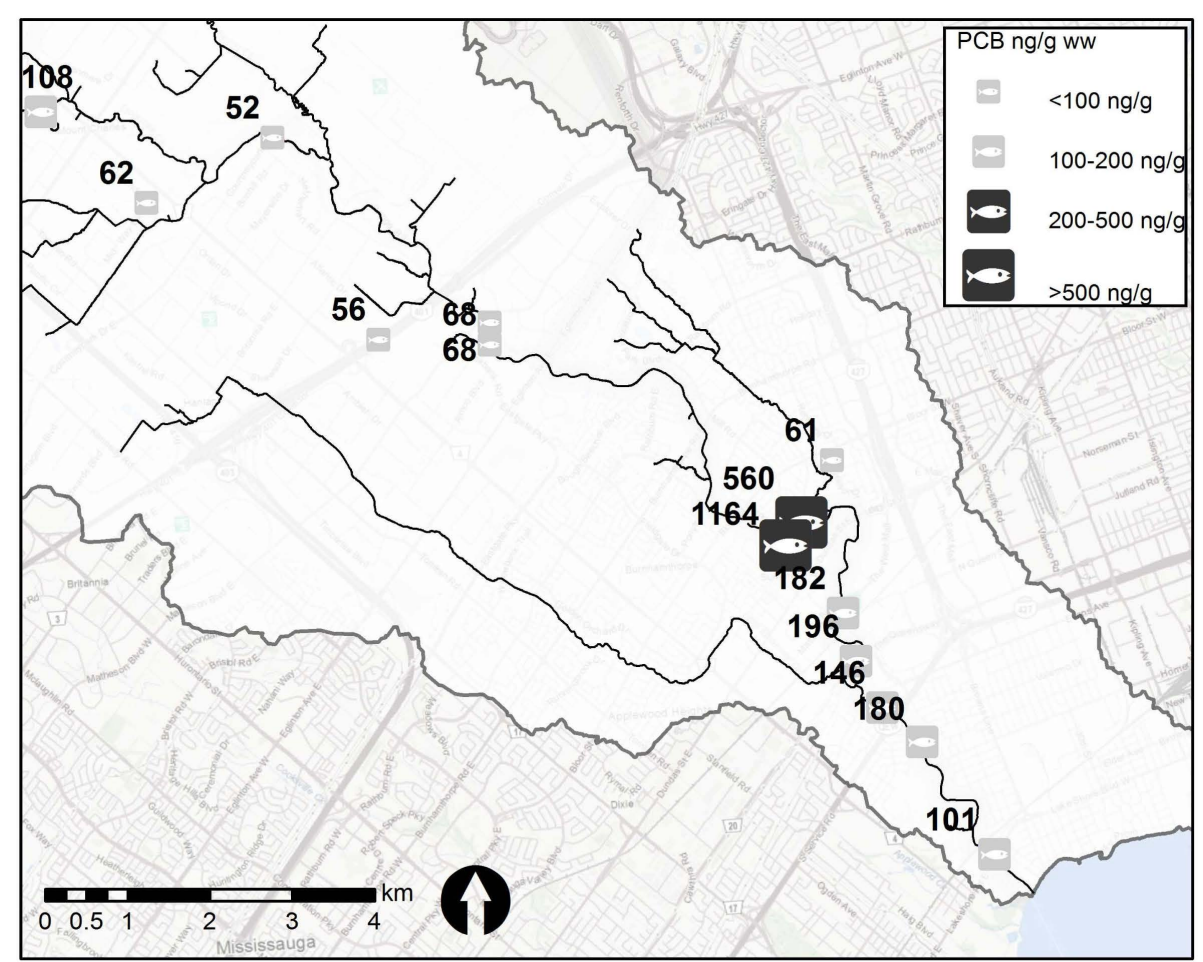

Figure 9. PCB concentrations in resident YOY forage fish tissue used as a line of evidence in identifying a potential source of localized PCB exposure. Typical samples consisted of composites of 5 fish. Where possible, up to five replicate samples were submitted. Light coloured fish diagrams depict tissue concentrations below $200 \mathrm{ng} / \mathrm{g}$ ww. Dark coloured fish diagrams show evidence of increased exposure due to a nearby source, triggering follow-up source tracking. Numbers listed above symbols show average concentrations in composites of up to 5 YOY common shiners (Notropsis cornutus).

a nearby source (e.g. Hamilton Harbour: [47]). Overall, the analysis of endemic YOY forage fish provides the most pragmatic approach to determining РСB bioavailability at an appropriate local scale to identify and asses the significance of the contamination.

\subsection{Does Contamination Matter If It's Not a Biological "Problem"? Prioritizing Action in the Trackdown Context}

The weight-of-evidence approach of using concurrent sampling media to identify the most contaminated areas within a watershed has proven useful in expediting source trackdown. However, given the overall goal of reducing harm to aquatic biota and ultimately their consumers, we consider indicators of bioavailability (evidence from passive samplers or biota themselves) to be the strongest lines of evidence for source trackdown leading to follow-up abatement actions. This fulfills a primary commitment of our agencies toward the Great Lakes Water Quality Agreement [48] and the Canada-Ontario agreement (COA) [49] to reduce the number of fish consumption advisories due to PCBs in the Great Lakes.

Although elevated concentrations of PCBs in water and sediment are generally associated with increased bioavailability, there have been rare instances where biotic samples indicated bioavailability that was not well correlated with total concentrations in the other media. This scenario generally indicates an exposure pathway that requires further exploration. Conversely, locally elevated concentrations in sediment and water have not always been associated with locally increased bioavailability. These situations demonstrate the lack of any exposure pathway and may be discounted from further follow-up actions [50].

Other factors, such as whether the source is locally controllable (i.e. not likely to reoccur after removal), play an important role in determining the viability of abatement and remediation. Jurisdictional regulatory factors come into play to determine which areas should be remediated: for example, if a significant source of contamination is within a "sensitive area" (i.e. located within $30 \mathrm{~m}$ of a surface water body: Ontario Regulation 153/04 
[51], such as contaminated soils within close proximity to a waterway sustaining aquatic life, priority for removal may be recommended.

\section{Conclusions}

The lessons learned from the pilot scale PCB Trackdown Program have been incorporated into an approach that has successfully led to cleanup and abatement activities in several watersheds on the Canadian side of the Great Lakes (Table 4) and that continues to be applied. Through this program, the provincial and federal partners have been able to respond to international commitments to improving Great Lakes water quality, one watershed at a time.

Table 4. Summary of Trackdown Project findings, compliance and remediation actions and resulting project evaluations and recommendations.

\begin{tabular}{|c|c|c|c|}
\hline Site & Finding & Compliance and remediation & Evaluation and recommendations \\
\hline \multicolumn{4}{|c|}{ Lake Ontario Sites } \\
\hline \multirow[t]{2}{*}{ Cataraqui River } & \multirow{2}{*}{$\begin{array}{l}\text { Localized "Hot Spot” } \\
\text { in Inner Harbour }\end{array}$} & $\begin{array}{l}\text { Removal of sediment contaminated } \\
\text { with PCBs, mercury, chromium, } \\
\text { arsenic and lead. }\end{array}$ & $\begin{array}{l}\text { Reduction in local sediment } \\
\text { PCB concentrations to } 1 \mathrm{ppm} \text {; } \\
\text { Some evidence of continued } \\
\text { contamination [53] }\end{array}$ \\
\hline & & $\begin{array}{l}500 \mathrm{~m}^{3} \text { PCB contaminated } \\
\text { sediment removed }\left(780 \mathrm{~m}^{3} \text { total }\right. \\
\text { contaminated sediment) }[52]\end{array}$ & $\begin{array}{l}\text { Recommendation for continued } \\
\text { assessment of contamination } \\
\text { in Inner Harbour }\end{array}$ \\
\hline Etobicoke Creek & $\begin{array}{l}\text { Identified easement with } \\
\text { PCB contaminated fill }\end{array}$ & $\begin{array}{l}\text { Remediation completed in 2014: } \\
1200 \mathrm{~m}^{3} \text { of PCB Contaminated } \\
\text { sediment removed along } \\
150 \mathrm{~m} \text { long easement }\end{array}$ & $\begin{array}{l}\text { Recommended evaluation } \\
\text { of recovery in 2016-17 }\end{array}$ \\
\hline \multirow{5}{*}{$\begin{array}{c}\text { Twelve-Mile Creek } \\
\text { Watershed }\end{array}$} & \multirow{4}{*}{$\begin{array}{c}\text { Two sources of contaminated } \\
\text { sediment in Beaverdams } \\
\text { Creek identified. }\end{array}$} & $\begin{array}{l}\text { Cleanup of contamination } \\
\text { in three phases: }\end{array}$ & $\begin{array}{l}\text { Reduction in sediment } \\
\text { contamination } \\
\text { (OMOE unpublished report) }\end{array}$ \\
\hline & & $\begin{array}{l}\text { Phase I (adjacent to major source): } \\
4812 \text { metric tonnes of PCB } \\
\text { contaminated sediment } \\
\text { removed along } 350 \mathrm{~m} \text { of creek. }\end{array}$ & $\begin{array}{c}\text { Reductions in PCB } \\
\text { concentrations in } \\
\text { YOY/forage fish tissue } \\
\text { (OMOE unpublished report) }\end{array}$ \\
\hline & & $\begin{array}{c}\text { Phase II } \\
\text { (downstream of major source): } 12,923 \\
\text { metric tonnes of } \\
\text { PCB contaminated sediment } \\
\text { removed along } 450 \mathrm{~m} \text { of creek. }\end{array}$ & \multirow[t]{2}{*}{$\begin{array}{l}\text { Recommended continued } \\
\text { monitoring to document recovery }\end{array}$} \\
\hline & & $\begin{array}{l}\text { Phase III (Secondary source): } \\
5374 \text { metric tonnes of } \\
\text { sediment removed } \\
\text { (for PCBs and heavy metals) } \\
\text { along } 950 \text { m of tributary ditch. } \\
\text { (OMOE unpublished) }\end{array}$ & \\
\hline & $\begin{array}{l}\text { Suspected landfill-based } \\
\text { source identified in } \\
\text { Twelve-Mile Creek tributary }\end{array}$ & $\begin{array}{l}\text { Ongoing discussion } \\
\text { with responsible parties }\end{array}$ & Not applicable \\
\hline \multicolumn{4}{|c|}{ Lake Erie/Detroit River Sites } \\
\hline Little River & $\begin{array}{l}\text { Discounted presence of } \\
\text { locally controllable sources }\end{array}$ & Not-applicable & Periodic monitoring \\
\hline Turkey Creek & $\begin{array}{c}\text { Identified erosion of side cast } \\
\text { material as source of } \\
\text { ongoing PCB and heavy } \\
\text { metal contamination to creek. }\end{array}$ & $\begin{array}{c}\text { Removal of approximately } 975 \mathrm{~m}^{3} \\
\text { of contaminated sediment along } \\
\text { Grand Marais Drain [31] }\end{array}$ & $\begin{array}{c}\text { Reduction in sediment } \\
\text { contamination; Reductions } \\
\text { in YOY fish tissue } \\
\text { (OMOE unpublished data 2012) }\end{array}$ \\
\hline
\end{tabular}


This paper summarizes the approach used in our trackdown studies and highlights the value of a congener specific analysis and a multimedia weight of evidence approach for identifying sources of PCBs to the environment. It also highlights the importance of including bioavailability as proven by uptake in organisms or their surrogates (passive samplers) as an important component to help prioritize the abatement or mitigation of contamination that has a direct effect on biota. With biota, our experience has shown that YOY forage fish are most suited for source trackdown because they have a workable threshold that compares to international guidelines (i.e. IJC), they are less vulnerable to substrate differences, enough tissue con be collected for appropriate analyses, and they integrate recent contamination over their lifetime.

Although site-specific circumstances make it difficult to provide certainty, the data generated through the pilot-scale work and subsequent application of the approach have flagged concentrations in water, sediment and biota that generally exceed concentrations associated with the "noise" of nonspecific PCB contamination typically found in urban environments. These can be considered as threshold concentrations that justify further exploration for local, discreet sources of PCBs due to an increased probability that they exist in an environment where it will always be possible to detect their presence.

The target watersheds for the findings reported herein ranged from partially rural/suburban sites to more industrialized areas. The program established thresholds in sediment, water and biota that could be used to distinguish local anomalies from background non-source areas in several Ontario watersheds. However, in highly industrialized areas, it is recognized that a second tier of thresholds may be warranted to separate local anomalies from generalized background contamination. Several aspects of this program have been adapted to such an environment in Hamilton, Ontario, where studies are currently being undertaken.

Our approach is initially intensive, but has proven to be efficient in finding locally controllable sources. Subsequently, the program becomes abatement intensive and requires the inclusion of compliance partners (regional offices) to engage responsible parties towards proper risk assessment and management strategies [14], and eventual source removal. Because historical contamination is often the ongoing locally controllable source, multiple partnerships between industry, local government and conservation authorities may be required to work together towards cleanup.

It is anticipated that many of the techniques used in the trackdown program may be applied to other legacy and emerging contaminants in and around the Great Lakes. In particular, our methods for project design (gathering background information, determining and reducing the area of interest in a step-wise fashion), setting triggers for further action in the various media, and the use of multiple lines of evidence converging to identify most probable source areas, may be useful for other practitioners in the field.

\section{Acknowledgements}

We thank the many participants in the trackdown work including substantial field assistance from John Kraft and Sean Backus (EC), Sarah Day, Dave Supper and Brian Thorburn (OMOECC). Satyendra Bhavsar provided supporting YOY forage fish data. We thank Paul Welsh, Paul Helm, Tanya Long, Lisa Trevisan and Eric Reiner for helpful comments on the manuscript.

\section{References}

[1] Suns, K.R., Hitchin, G.G. and Toner, D. (1993) Spatial and Temporal Trends of Organochlorine Contaminants in Spottail Shiners from Selected Sites in the Great Lakes (1975-1990). Journal of Great Lakes Research, 19, 703-714. http://dx.doi.org/10.1016/S0380-1330(93)71258-7

[2] Brooks, K., Fleury, J.P.F., Raymond, J.G.Y. and Reinhardt, A.M. (1999) An Environmental Evaluation of the River Sediments Surrounding the Belle Island Landfill, Kingston, Ontario. Unpublished Thesis, Royal Millitary College, Kingston, ON.

[3] Dove, A., Painter, S. and Kraft, J. (2004) Sediment Quality in Canadian Lake Ontario Tributaries: Part Two (Bay of Quinte and St. Lawrence River): A Screening-Level Survey. ECB/EHD-OR/04-01/I.

[4] Dove, A., Fletcher, R., Derry, A., Benoit, N. and Boyd, D. (2003) Interim Guidance Framework for PCB Source Track-Down Projects. ECB/EHD-OR/03-04/I.

[5] Dove, A., Painter, S. and Kraft, J. (2003) Sediment Quality in Canadian Lake Ontario Tributaries—Part One (West of the Bay of Quinte): A Screening-Level Survey. April 2003, Report No. ECB/EHD-OR/03-01/I.

[6] Boyd, D. and Biberhofer, J. (1999) Large Volume Sampling at Six Lake Ontario Tributaries during 1997 and 1998 : 
Project Synopsis and Summary of Selected Results. OMOE PIBS 3927E Queen’s Printer for Ontario, 1-43.

[7] Dove, A., Painter, S. and Kraft, J. (2002) Sediment Quality in Canadian Lake Erie Tributaries: A Screening-Level Survey. September 2002, Report No. ECD/EHD-OR/02-05/I.

[8] Boyd, D., D’Andrea, M. and Anderton, R. (1999) Assessment of Six Tributary Discharges to the Toronto Area Waterfront Volume 2: Technical Appendix and Data Summary.

[9] Boyd, D. (1999) Assessment of Six Tributary Discharges to the Toronto Area Waterfront Volume 1: Project Synopsis and Selected Results. Report Prepared for the Toronto and Region Remedial Action Plan.

[10] Lake Ontario LaMP (2002) Lake Ontario LaMP 2002 Report. April 2002.

[11] Ontario Ministry of the Environment (OMOE) (2013) Guide to Eating Ontario Sport Fish 2013-2014. Twenty-Seventh Edition, Revised, Queen's Printer for Ontario.

[12] Shelton, L.R. and Capel, P.D. (1994) Guideline for Collecting and Processing Samples of Stream Bed Sediment for Analysis of Trace Elements and Organic Contaminants for the National Water-Quality Assessment Program. US Geological Survey Open-File Report 94-458.

[13] Drouillard, K.G., Tomczak, M., Reitsma, S. and Haffner, G.D. (2006) A River-Wide Survey Polychlorinated Biphenyls (PCBs), Polycyclic Aromatic Hydrocarbons (PAHs), and Selected Organochlorine Pesticide Residues in Sediments of the Detroit River-1999. Journal of Great Lakes Research, 32, 209-226. http://dx.doi.org/10.3394/0380-1330(2006)32[209:ARSOPB]2.0.CO;2

[14] Jia, J., Thiessen, L., Schachtschneider, J., Waltho, J. and Marvin, C. (2010) Contaminant Trends in Suspended Sediments in the Detroit River-Lake St.Clair-St. Clair River Corridor, 2000 to 2004. Water Quality Research Journal of Canada, 45, 69-80.

[15] Fletcher, R., Welsh, P. and Fletcher, T. (2008) Guidelines for Identifying, Assessing and Managing Contaminated Sediment in Ontario: An Integrated Approach. Ontario Ministry of the Environment Standards Development Branch, PIBS 6658e, Queen's Printer for Ontario.

[16] Suns, K. and Rees, G.A. (1978) Organochlorine Contaminant Residues in Young-of-the-Year Spottail Shiners from Lakes Ontario, Erie, and St. Clair. Journal of Great Lakes Research, 4, 230-233. http://dx.doi.org/10.1016/S0380-1330(78)72190-8

[17] International Joint Commission (IJC) (1987) Revised Great Lakes Water Quality Agreement of 1978 as Amended by Protocol, Signed November 18, 1987. Governments of the United States and Canada.

[18] Bhavsar, S., Awad, E., Mahon, C. and Petro, S. (2011) Great Lakes Fish Consumption Advisories: Is Mercury a Concern? Ecotoxicology, 20, 1588-1598. http://dx.doi.org/10.1007/s10646-011-0731-0

[19] Gewurtz, S.B., Backus, S.M., Bhavsar, S.P., McGoldrick, D.J., de Solla, S.R. and Murphy, E.W. (2011) Contaminant Biomonitoring Programs in the Great Lakes Region: Review of Approaches and Critical Factors. Environmental Reviews, 19, 162-184. http://dx.doi.org/10.1139/a11-005

[20] Richman, L.A., Hobson, G., Williams, D.J. and Reiner, E. (2011) The Niagara River Mussel Biomonitoring Program (Elliptio complanata): 1983-2009. Journal of Great Lakes Research, 37, 213-225. http://dx.doi.org/10.1016/j.jglr.2011.03.012

[21] Benoit, N. and Dove, A. (2006) Polychlorinated Biphenyl Source Track-Down in the Cataraqui River: Results of the 2002 and 2003 Monitoring Programs. Unpublished Internal Technical Report Prepared for Eastern Region Ministry of the Environment.

[22] COA (2008) Canada-Ontario Agreement Respecting the Great Lakes Basin Ecosystem. 2002-2007 Progress Report Published by Environment Canada and the Ontario Ministry of the Environment. Queen's Printer for Ontario.

[23] Lake Ontario LaMP (2006) Source Reduction Activities in Ontario in Lake Ontario Lakewide Management Plan. Update '06

[24] Benoit, N. and Day, S. (2013) Carter and Clifford Creek PCB Watershed Study. 2010 Technical Memorandum, Unpublished Internal Report.

[25] Huckins, J.N., Manuweera, G.K., Petty, J.D., Mackay, D. and Lebo, J.A. (1993) Lipid-Containing Semi-Permeable Membrane Devices for Monitoring Organic Contaminants in Water. Environmental Science and Technology, 27, 24892496. http://dx.doi.org/10.1021/es00048a028

[26] Metcalfe, T. (2003) Trent University Pers. Comm.

[27] Booij, K., Hofmans, H.E., Fischer, C.B. and Van Weerlee, E.M. (2003) Temperature-Dependent Uptake Rates of Nonpolar Organic Compounds by Semipermeable Membrane Devices and Low-Density Polyethylene Membranes. Environmental Science and Technology, 37, 361-366. http://dx.doi.org/10.1021/es025739i

[28] Huckins, J., Booij, K. and Petty, J. (2006) Fundamentals of SPMDs. In: Huckins, D., Petty, J.N. and Booij, K., Eds., 
Monitors of Organic Chemicals in the Environment, Springer, New York, 29-43. http://dx.doi.org/10.1007/0-387-35414-x_2

[29] Benoit, N. and Burniston, D. (2006) Practical Applications of Semi-Permeable Membrane Devices (SPMDs) in a Weight-of-Evidence Approach to Tracking Sources of Polychlorinated Biphenyls (PCB). Presented to Society of Environmental Toxicology and Chemistry, November, 2006, Montreal, Canada.

[30] Benoit, N. and Burniston, D. (2010) Tracking PCB Contamination in Great Lakes Tributaries. Proceedings of the International Association of Great Lakes Research Conference, Toronto, 17-21 May 2010.

[31] Green, N.D., Cargnelli, L., Briggs, T., Drouin, R., Child, M., Esbjerg, J., Valiante, M., Henderson, T., McGregor, D. and Munor, D., Eds. (2010) Detroit River Canadian Remedial Action Plan: Stage 2 Report. Detroit River Canadian Cleanup, Publication No. 1, Essex, Ontario.

[32] National Research Council (NRC), Committee on Remediation of PCB-Contaminated Sediments, Board on Environmental Studies and Toxicology (2001) Methods of Analysis of PCBs in Sediments, Water and Biota. In: National Research Council, Ed., A Risk Management Strategy for PCB-Contaminated Sediments, National Academy Press, Washington DC, 334-362.

[33] Johnson, G.W., Quensen, I.J.F., Chiarenzelli, J.R. and Hamilton, M.C. (2005) Polychlorinated Biphenyls. In: Morrison, R. and Murphy, B., Eds., Environmental Forensics, Academic Press, London, 188-225.

[34] OMOE (2010) PCBC-E3459: The Determination of Polychlorinated Biphenyl (PCBs) Congeners in Aqueous Samples by Gas-Chromatography-High Resolution Mass Spectrometry (GC-HRMS).

[35] Babut, M., Miege, C., Villeneuve, B., Abarnou, A., Duchemin, J., Marchand, P. and Narbonne, J.F. (2009) Correlations between Dioxin-Like and Indicators PCBs: Potential Consequences for Environmental Studies Involving Fish or Sediment. Environmental Pollution, 157, 3451-3456. http://dx.doi.org/10.1016/j.envpol.2009.06.016

[36] Frame, G.M., Cochran, J.W. and Bøwadt, S.S. (1996) Complete PCB Congener Distributions for 17 Aroclor Mixtures Determined by 3 HRGC Systems Optimized for Comprehensive, Quantitative, Congener-Specific Analysis. Journal of High Resolution Chromatography, 19, 657-668. http://dx.doi.org/10.1002/jhrc.1240191202

[37] Reiner, E. (2014) OMOE 2014, Pers. Comm.

[38] Oliver, B.G. and Niimi, A.J. (1988) Trophodynamic Analysis of Polychlorinated Biphenyl Congeners and Other Chlorinated Hydrocarbons in the Lake Ontario Ecosystem. Environmental Science and Technology, 22, 388-397. http://dx.doi.org/10.1021/es00169a005

[39] Wong, C.S., Mabury, S.A., Whittle, D.M., Backus, S.M., Teixeira, C., Devault, D.S., Bronte, C. and Muir, D.C.G. (2004) Organochlorine Compounds in Lake Superior: Chiral Polychlorinated Biphenyls and Biotransformation in the Aquatic Food Web. Environmental Science and Technology, 38, 84-92. http://dx.doi.org/10.1021/es0346983

[40] Hu, D., Martinez, A. and Hornbuckle, K.C. (2011) Sedimentary Records of Non-Aroclor and Aroclor PCB Mixtures in the Great Lakes. Journal of Great Lakes Research, 37, 359-364.

[41] Johnson, G.W. and Ehrlich, R. (2002) State of the Art Report on Multivariate Chemometric Methods in Environmental Forensics. Environmental Forensics, 3, 59-79.

[42] ter Braak, C.J.F. (1995) Ordination. In: Jongman, R.H.G., ter Braak, C.J.F. and van Tongeren, O.F.R., Eds., Data Analysis in Community and Landscape Ecology, Cambridge University Press, Cambridge, 91-173. http://dx.doi.org/10.1017/CBO9780511525575.007

[43] Rachdawong, P. and Christensen, E.R. (1997) Determination of PCB Sources by a Principal Component Method with Nonnegative Constraints. Environmental Science and Technology, 37, 2686-2691. http://dx.doi.org/10.1021/es970107v

[44] Canadian Council of Ministers of the Environment (CCME) (1999) Canadian Environmental Quality Guidelines. Canadian Council of Ministers of the Environment, Winnipeg.

[45] Persaud, D., Jaagumagi, R. and Hayton, A. (1993) Guidelines for the Protection and Management of Aquatic Sediment Quality in Ontario. Ontario Ministry of Environment and Energy.

[46] Phillips, P.J., Riva-Murray, K., Hollister, H.M. and Flanary, E.A. (1997) Distribution of DDT, Chlordane, and Total PCB's in Bed Sediments in the Hudson River Basin. New York Earth Science and the Environment, 3, $26-37$.

[47] Labencki, T. (2008) An Assessment of Polychlorinated Biphenyls (PCBs) in the Hamilton Harbour Area of Concern (AOC) in Support of the Beneficial Use Impairment (BUI): Restrictions on Fish and Wildlife Consumption. Written on Behalf of Toxic Substances and Sediment Technical Team Hamilton Harbour Remedial Action Plan.

[48] Great Lakes Water Quality Agreement (GLWQA) (2012) Protocol Amending the Agreement between Canada and the United States of America on Great Lakes Water Quality, 1978, As Amended on October 16, 1983 and on November 18, 1987.

[49] OMOE-Environment Canada (2002) Canada-Ontario Agreement Respecting the Great Lakes Basin Ecosystem.

[50] Benoit, N. (2006) Results of the Turkey Creek Trackdown Study: Data from Walker Road to Central Avenue 
2004-2006. Internal Technical Memorandum Prepared for South Western Region, Ontario Ministry of the Environment.

[51] Ontario Regulation 153/04: Records of Site Condition-Part XV.1 of the Act. http://www.e-laws.gov.on.ca/html/regs/english/elaws_regs_040153_e.htm

[52] Benoit, N. and Burniston, D. (2010) Cataraqui River Project Trackdown: Follow-Up Study on Success of Remediation Efforts in the Cataraqui River 2006. Internal Technical Memorandum Prepared for Eastern Region Ministry of the Environment, April, 2010.

[53] Ontario Ministry of the Environment and Energy (1994) Water Management Policies, Guidelines, Provincial Water Quality Objectives of the Ministry of Environment and Energy. Queen’s Printer for Ontario, PIBS 3303E. 